\title{
Evaluation of agro-industrial residues produced in Costa Rica for a low-cost culture medium using Bacillus subtilis 168
}

\section{Evaluación de residuos agroindustriales producidos en Costa Rica para la formulación de un medio de cultivo de bajo costo utilizando Bacillus subtilis 168}

Sofía Miranda-Durán ${ }^{1}$, Luis Porras-Reyes², Alexander Schmidt-Durán ${ }^{3}$

Fecha de recepción: 28 de octubre de 2019

Miranda-Durán, S; Porras-Reyes, L; Schmidt-Durán, A. Evaluation of agro-industrial residues produced in Costa Rica for a low-cost culture medium using Bacillus subtilis 168. Tecnología en Marcha. Vol. 33-4. Octubre-Diciembre 2020.

Pág 15-25.

doi https://doi.org/10.18845/tm.v33i4.4807

1 Ingeniera en Biotecnología. Agencia Universitaria para la Gestión del emprendimiento, Universidad de Costa Rica. Costa Rica. Correo electrónico: sofia.miranda@augeucr.com.

2 Ingeniero en Biotecnología. Centro Nacional de Innovaciones Biotecnológicas (CENIBiot-CeNAT), Consejo Nacional de Rectores. Centro en Investigaciones Agronómicas (CIA), Universidad de Costa Rica. Costa Rica. Correo electrónico: luis.porrasreyes@ucr.ac.cr. 


\title{
Keywords
}

Agro-industrial residues; biomass; growth optimization; Bacillus subtilis 168; circular economy.

\begin{abstract}
Agro-industrial residues correspond to all the materials generated from activities that involve the transformation of both crops and livestock to obtain processed or semi-finished products. In Costa Rica, the primary sector of economy generates more than 6.3 trillion tons of organic residues per year. The daily generation of these residues pose environmental and economic problems. In recent years, biotechnological-based alternatives have emerged with the purpose of taking advantage of the high nutritional content of these residues to cultivate microorganisms capable of producing compounds with high demand at a commercial level. The present study evaluates six agro-industrial residues produced in Costa Rica, in order to grow Bacillus subtilis 168. An optimization of the culture medium was carried out under a complete factorial design $2^{3}$, where the variables evaluated were carbon, nitrogen and phosphorus sources. Molasses at $10 \%$ $\mathrm{m} / \mathrm{v}$, wheat bran at $0.5 \% \mathrm{~m} / \mathrm{v}$, and $\mathrm{K}_{2} \mathrm{HPO}_{4} \mathrm{~m} / \mathrm{v}$ at $0.01 \%$, as a carbon, nitrogen, and phosphorus sources, respectively, were identified as optimal for the growth of Bacillus subtilis 168.
\end{abstract}

\section{Palabras clave}

Residuos agroindustriales; biomasa; optimización del crecimiento; Bacillus subtilis 168; economía circular.

\section{Resumen}

Los residuos agroindustriales corresponden a todos aquellos subproductos que son generados a partir de las actividades que involucran una transformación de materias, tanto agrícolas como ganaderas. En Costa Rica se generan más de 6,3 billones de toneladas de residuos orgánicos solo en el sector económico primario. Estos residuos suponen una problemática tanto ambiental como económica. En los últimos años, han surgido alternativas de base biotecnológicas en busca de la valorización de residuos agroindustriales que permitan aprovechar su contenido nutricional para cultivar microorganismos capaces de producir compuestos con alta demanda a nivel comercial. Bajo esta premisa, el presente estudio evaluó seis residuos agroindustriales producidos en Costa Rica para el crecimiento de Bacillus subtilis 168. Además, se llevó a cabo una optimización del medio de cultivo bajo un diseño factorial completo $2^{3}$, donde las variables evaluadas fueron fuente de carbono, nitrógeno y fósforo. Melaza al 10\% m/v, salvado de trigo al 0,5\% $\mathrm{m} / \mathrm{v}$ y $\mathrm{K}_{2} \mathrm{HPO}_{4}$ al 0,01\% como fuentes de carbono, nitrógeno y fósforo, respectivamente, fueron los parámetros óptimos para el crecimiento de Bacillus subtilis 168.

\section{Introduction}

Agro-industrial production processes for the generation of food or semi-processed raw materials are a source of solid and liquid wastes or agro-industrial byproducts [1]. The daily generation of high volumes of wastes and by-products carry several problems with serious environmental damages. This problem has increased the interest of producers, industries, and technologists to find alternatives to exploit these wastes and by-products in order to transform them into valueadded products [2]. 
In recent years, the development of technologies concerning the use of industrial wastes has been growing. For example, wastes and byproducts from the agro-industrial processing of corn, wheat, rice, sugar, beet, potato and tapioca crops stands out, in order to obtain products such as enzymes, a wide range of solvents, food additives, agrochemicals and biofuels [3] [4] [5] [6]. This transformation processes are mediated, in part, by yeasts, bacteria, fungi, and microalgae whose metabolic characteristics make them suitable for the synthesis of high value-added molecules from agro-industrial residues (AR) [7] [8].

In this context, the use of AR not only has benefits to environmental issues but also implies potential economic benefits. Therefore, currently there is an increasing number of industries using biomass wastes to generate high-value products by adopting biotechnological methodologies in their processes [9].

Bacillus subtilis is widely used in fermentation processes based on AR as substrates [10]. This fact is largely due to the ability of this microorganism to metabolize a wide group of sugars present in AR. In addition, it can produce up to eight proteases classified into two large groups: serine proteases and metalloproteases that collaborate in the degradation of complex sugars [11]. This Gram-positive bacterium is a model microorganism, playing a crucial role in academic and industrial research [12]. The strain Bacillus subtilis 168, single tryptophan requiring auxotroph, is considerate a highly transformable strain used for basic research and as an industrial workhorse [10]. Therefore, this study refers to the use of agro-industrial sources to develop a low-cost culture medium used for Bacillus subtilis 168 biomass production. Besides, this research is part of a project that seeks to produce commercially attractive levels of small metabolites by using recombinant Bacillus subtilis 168 strains.

\section{Material and methods}

\section{Microorganism and culture conditions}

The present project was carried out in the laboratories of the Bioprocesses Unit of the National Center for Biotechnological Innovations (CENAT-CENIBiot), located in Pavas, San José, Costa Rica. The strain used for the development of this research was Bacillus subtilis 168 (GBSC code 1A771) obtained from Bacillus Genetic Stock Center, Ohio, United States of North America. Subcultures of this bacterium were carried out using Lysogeny agar medium (Miller) and incubated at $37^{\circ} \mathrm{C}$ for 24 hours. The strain was stored at $-80^{\circ} \mathrm{C}$ in $15 \% \mathrm{v} / \mathrm{v}$ glycerol stocks [13].

\section{Culture media preparation}

The selection criteria were based on nutritional content [14] [15] [16], local availability, management and cost (table 1). PM, LM, WB, CP and BG were prepared in $10 \% \mathrm{~m} / \mathrm{v}$ solutions using osmosis water. The solutions were centrifuged at $4000 \times$ g during 15 min (Hettich, Model Roto Silenta 630RS) in order to eliminate suspended solids. For CE, the effluent was used directly as the culture medium. The sucrose content in all media was carried out in triplicates using the biochemical analyzer (YSI, Model 2700). When necessary, up to $23 \mathrm{~g} / \mathrm{L}$ of sucrose was supplemented in the substrate prior to sterilization. Each substrate was adjusted to a pH value of 7.2. Finally, each substrate was sterilized in autoclave for $20 \mathrm{~min}$ at $121^{\circ} \mathrm{C}$. For the BG culture medium, it was necessary to decant the solids after the sterilization process. 


\section{Preliminary tests}

Preliminary tests were carried out in order to determine key sampling points and selection of the most appropriate AR.

A $15 \mathrm{~mL}$ microbial inoculum (50 mL Falcon tube) with LB medium was prepared with one full loop colony (3-4 mm of diameter). It was left overnight at $37^{\circ} \mathrm{C}$ and $150 \mathrm{rpm}$. Experiment flasks with $60 \mathrm{~mL}$ (in $250 \mathrm{~mL}$ flasks) of the corresponding AR medium (inoculated with 10\% v/v inoculum) were incubated during $48 \mathrm{~h}$, at $37^{\circ} \mathrm{C}$, and $150 \mathrm{rpm}$. For the CE and WB media, the sampling time was extended up to 52 hours. Cell viability was determined by the decimal serial dilution method. Standard plate count agar was used for the estimation of CFU.

Table 1. Costs associated to agriculture residues used in this study.

\begin{tabular}{|c|c|}
\hline Agriculture residue & Cost \\
\hline Powder molasses (PM) & $\$ 3 / \mathrm{Kg}$ \\
\hline Liquid molasses (LM) & $\$ 1.5 / \mathrm{L}$ \\
\hline Corn wet mill effluents (CE) & Free \\
\hline Wheat bran (WB) & $\$ 0.15 / \mathrm{Kg}$ \\
\hline Brewers' spent grain (BG) & Free \\
\hline Coffee pulp (CP) & Free \\
\hline
\end{tabular}

\section{AR selection for biomass production}

According to preliminary tests, two agro-industrial residues, PM and CP, were discarded due to their low biomass production yields (data not shown). For the others AR, assays were carried out in $60 \mathrm{~mL}$ of medium (in $250 \mathrm{~mL}$ flasks) during $48 \mathrm{~h}$, at $37^{\circ} \mathrm{C}$, and $200 \mathrm{rpm}$. These cultures were inoculated with a $10 \% \mathrm{v} / \mathrm{v}$ inoculum prepared overnight at $37^{\circ} \mathrm{C}$ and $200 \mathrm{rpm}$. Assays were done in triplicates. Sampling was carried out at 0, 8, 24 and 48 hours. Cell viability was determined by the decimal serial dilution method. Standard plate count agar was used for the estimation of CFU.

The selection of the culture medium was carried out through a one-way ANOVA test with 95\% confidence, using cell viability data (transformed to $\log _{10}$ ) taken after 24 hours of fermentation. A Tukey multiple comparison test was performed with 95\% confidence using Minitab $®$ statistical program [17].

\section{Selection of nitrogen source}

The LM was used as the base AR to evaluate three different nitrogen sources: ammonium nitrate $\left(\mathrm{NH}_{4} \mathrm{NO}_{3}\right)(\mathrm{AN})$ as an inorganic nitrogen source, wheat bran (WB) and yeast extract (YE) as organic nitrogen sources. The statistical analysis to select the nitrogen source was carried out by one-way ANOVA test with 95\% confidence. The cell viability data (transformed to $\log _{10}$ ) was collected after 24 hours of fermentation. A Tukey multiple comparison test was performed with $95 \%$ confidence. 


\section{Culture medium optimization: Factorial design $2^{3}$.}

A full factorial design $2^{3}$ was carried out to determine significant factors of AR, nitrogen and phosphorus sources for Bacillus subtilis 168 biomass production (table 2). The selection of the most suitable inorganic source of phosphorus was based on the literature [7]. A confirmation of the model was performed in triplicates based in the defined optimal conditions. This confirmation was also tested against a control treatment using Lysogenyc Broth (LB) culture medium. The cell viability data (transformed to $\log _{10}$ ) obtained were analyzed through a one-way ANOVA analysis.

Table 2. Factorial design $2^{3}$ for carbon, nitrogen and phosphorus sources in the culture media.

\begin{tabular}{|c|c|c|c|c|}
\hline \multirow{2}{*}{ Factor } & \multirow{2}{*}{ Code } & \multicolumn{3}{|c|}{ Level $(\% \mathrm{~m} / \mathrm{v})$} \\
\hline & & -1 & 0 & +1 \\
\hline$A R(L M)$ & C & 5 & 7.5 & 10 \\
\hline Nitrogen source (WB) & $\mathrm{N}$ & 0.5 & 0.75 & 1 \\
\hline Phosphorus source $\left(\mathrm{K}_{2} \mathrm{HPO}_{4}\right)$ & $\mathrm{P}$ & 0.01 & 0.15 & 0.3 \\
\hline
\end{tabular}

\section{Results and discussion}

According to the preliminary tests, microorganism growing in the agro-industrial residues PM and CP evidenced the lowest cell concentration values, after 32 hours of fermentation with $2.5 \mathrm{x}$ $10^{3} \mathrm{CFU} / \mathrm{mL}$ and $3.0 \times 10^{3} \mathrm{CFU} / \mathrm{mL}$ respectively. Meanwhile, the media elaborated with LM and WB presented the best results in this stage of preliminary test with $7.3 \times 10^{8}$ and $7.4 \times 10^{8} \mathrm{CFU} /$ $\mathrm{mL}$. Finally, for CE and BG after 32 hours of fermentation presented $5.7 \times 10^{7}$ and $4.9 \times 10^{7} \mathrm{CFU} /$ $\mathrm{mL}$ respectively.

$\mathrm{CP}$ has high contents of carbohydrates, proteins, and minerals that has made this substrate a raw material frequently used in bioprocess [18]. However, the growth of Bacillus subtilis 168 during the preliminary trials was not optimal considering the objective of biomass production as it maintained a cell viability between $1.5 \times 10^{3}$ and $3.0 \times 10^{3} \mathrm{CFU} / \mathrm{mL}$. Even though coffee pulp is rich in carbohydrates (21-32\%), protein (7.5-15.0\%) and fat (2.0-7.0\%), it also presents antiphysiological and antinutritional factors like tannins, polyphenols and caffeine [19], which could be limiting the microbial growth. Similar results, in terms of cell growth deficiency, is observed for culture medium PM, as the cell growth remained between $5.0 \times 10^{2}$ and $2.5 \times 10^{3}$ $\mathrm{CFU} / \mathrm{mL}$.

On the other hand, the LM culture medium reached one of the highest cell growth values during the preliminary trials, with a concentration that reached $7.2 \times 10^{8} \mathrm{CFU} / \mathrm{mL}$ after 20 hours of fermentation. Even though both culture media were prepared at $10 \% \mathrm{~m} / \mathrm{v}$ with AR molasses, the nutritional contents could vary between the two types of molasses used in this work. One of the factors that can cause nutritional heterogeneity among molasses is related to the source of the materials and the transformation processes they are submitted to during industrial activities [20].

In order to produce more than $1.0 \times 10^{7} \mathrm{CFU} / \mathrm{mL}$ cell concentration; it was decided to discard PM and CP as an AR for Bacillus subtilis 168 medium and to continue trials with LM, CE, WB and GB.

According to the one-way ANOVA analysis, the null hypothesis was rejected with a p-value of 0.032. According to the Tukey test, the best results in terms of cell viability corresponds to WB, which reached a cell concentration of $1.4 \times 10^{8}$ at 8 hours of fermentation (figure 1). However, the Tukey analysis grouped this medium with LM, BG and LB (control), so there are no significant 
differences in terms of cell growth. On the other hand, CE, which has the lowest cell viability, is grouped with $L M, B G$, and LB. This indicates that there is a significant difference between culture media CE and WB (table 3).

In the other hand, at 24 hours, the one-way ANOVA analysis determined that there are significant differences between treatments, with a $\mathrm{p}$-value $=0.000$. The Tukey test determined that the LB culture medium was the one that obtained the highest biomass and presented significant differences with the rest of AR media (table 3).

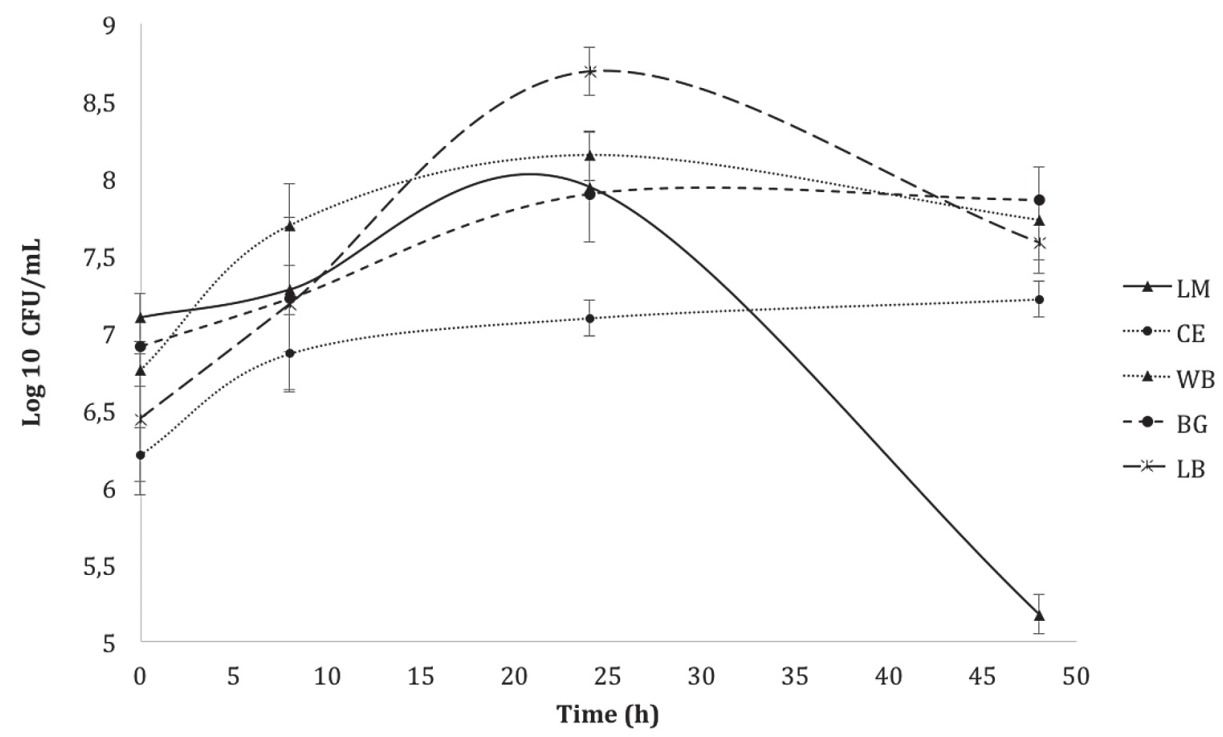

Figure 1. Bacillus subtilis growth curve using four agro-industrial residues as a culture medium. The results are expressed as an average \pm SD of biological replicas.

In the absence of significant differences within WB, LM and BG at 8 and 24 hours, the selection of the AR was based in the next criteria for bioprocesses: availability and management. LM has been widely reported as a suitable substrate for biocompost production and microorganism's growth, including B. subtilis [21], as it is easy to use and is a low-cost material. In addition, since sugar is a product widely exploited in countries such as Brazil, India, United States and China [22] and this residue can be readily available in Costa Rica, the LM was the AR chosen.

Table 3. Cell viability at 8 and 24 h using different agro-industrial residues.

\begin{tabular}{|c|c|c|}
\hline Culture media & CFU/mL average after $8 \mathrm{~h}^{\star}$ & CFU/mL average after $24 \mathrm{~h}^{*}$ \\
\hline WB & $4.9 \times 10^{7} \mathrm{a}$ & $1.4 \times 10^{8} \mathrm{~b}$ \\
\hline LM & $1.9 \times 10^{7} \mathrm{ab}$ & $8.7 \times 10^{7} \mathrm{~b}$ \\
\hline BG & $1.7 \times 10^{7} \mathrm{ab}$ & $7.8 \times 10^{7} \mathrm{~b}$ \\
\hline CE & $7.3 \times 10^{6} \mathrm{~b}$ & $1.2 \times 10^{7} \mathrm{~b}$ \\
\hline LB $^{* \star}$ & $1.5 \times 10^{7} \mathrm{ab}$ & $4.9 \times 10^{8} \mathrm{a}$ \\
\hline
\end{tabular}

* Averages that do not share a letter are significantly different with $\alpha=0.05$ according to Tukey's statistical test.

** Medium control (Lysogeny Broth) 


\section{Culture medium Optimization}

Based on the growth curves obtained and statistical analysis performed (figure 2 and table 4), a change in viability is observed for some treatments with respect to their cell growth at 8 and 24 hours of fermentation. At 8 hours of fermentation, two groups defined according to Tukey tests can be observed, where the best cell growth values are given for WB treatment and the control (LM), AN and YE treatments have the lowest cell viability results. After 24 hours of fermentation, the AN treatment shows a considerable improvement with the highest biomass production. AN treatment manages to be grouped within the best treatments according to the statistical test performed. Besides, the YE treatment and the control reached the death phase at this time. Tabbene and coworkers [23] mentioned that this effect may be due in part to the ability of organic sources to be used as a source for direct amino acids synthesis by the microbial metabolism, which would explain the result observed when using WB. WB is reported as a protein rich substrate [24].

Therefore, considering that the evaluated inorganic source can extend the fermentation process, and this could lead to an increase in process costs, treatment WB has been selected as the best source of nitrogen. Besides, there are no significant differences with the treatment AN and shows an adequate assimilation by Bacillus subtilis 168.

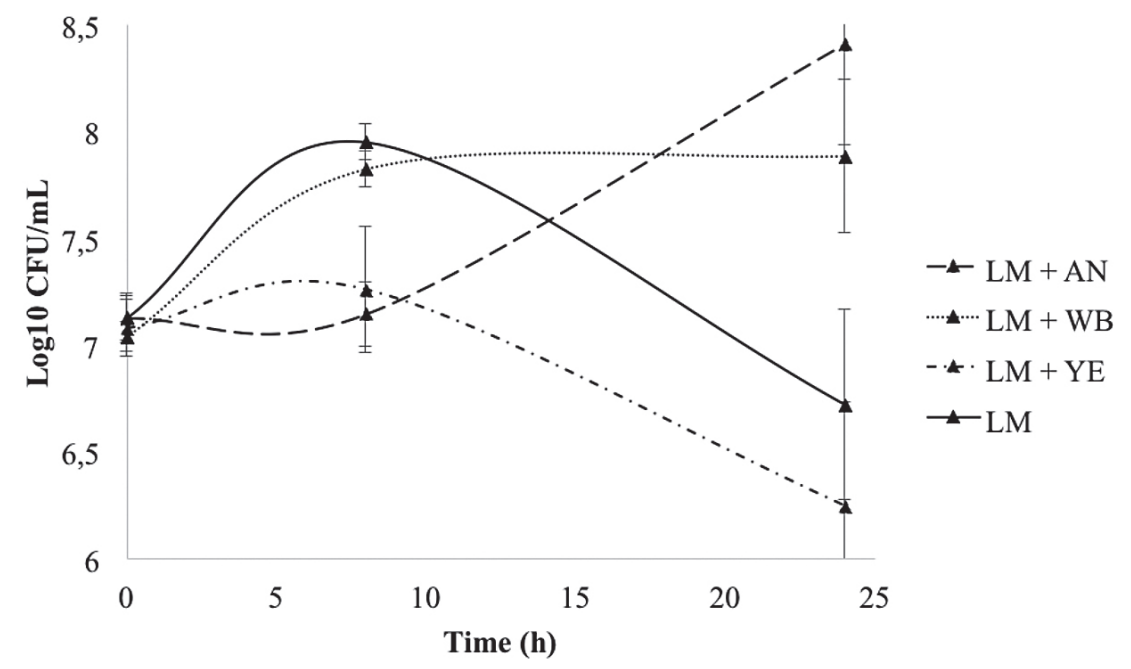

Figure 2. Bacillus subtilis 168 growth curve using LM (control) as supplemented with three sources of nitrogen: AN, WB and YE. The results are expressed as an average \pm SD of biological replicas

Table 4. Cell viability at 8 and 24 h using different nitrogen sources.

\begin{tabular}{|c|c|c|}
\hline Nitrogen source treatment & CFU/mL average after $8 \mathrm{~h}^{\star}$ & $\mathrm{CFU} / \mathrm{mL}$ average after $24 \mathrm{~h}^{\star}$ \\
\hline $\mathrm{AN}$ & $1.4 \times 10^{7} \mathrm{~b}$ & $2.5 \times 10^{8} \mathrm{a}$ \\
\hline $\mathrm{WB}$ & $6.6 \times 10^{7} \mathrm{a}$ & $7.6 \times 10^{7} \mathrm{a}$ \\
\hline $\mathrm{YE}$ & $1.8 \times 10^{7} \mathrm{~b}$ & $1.4 \times 10^{5} \mathrm{~b}$ \\
\hline$L M^{\star *}$ & $8.9 \times 10^{7} \mathrm{a}$ & $6.0 \times 10^{6} \mathrm{~b}$ \\
\hline
\end{tabular}

* Averages that do not share a letter are significantly different with $\alpha=0.05$ according to Tukey's statistical test.

** Medium control 
The statistical analysis shows that after analyzing each factor individually, the sources of nitrogen and phosphorus used are significant factors that affect the cellular growth of Bacillus subtilis ( $p=0.001$ and $p=0.001$, respectively). However, the carbon source alone does not have a significant effect $(p=0.075)$. Interestingly, the carbon source has a significant effect when there is an interaction with nitrogen and phosphorus. Significant effect of all interactions between two factors on cell growth can be observed (figure 3). Due to the significant interaction between the carbon and nitrogen sources, a greater cell viability can be observed when the two variables reach the highest values, $5 \mathrm{~g} / \mathrm{L}$ and $8 \mathrm{~g} / \mathrm{L}$, respectively.

On the other hand, when assessing the interaction of the carbon source and phosphorus source factors, it can be observed that for low phosphorus and high carbon values, the best cell growth is obtained. Finally, the interaction of the phosphorus source with the nitrogen source shows that at a low concentration of phosphorus and at a high nitrogen concentration, a higher cell growth is reached for high concentrations of carbon and nitrogen, compared to low concentrations of phosphorus, the best biomass production is obtained. The interaction of the three factors is significant $(p=0.003)$ as the components of the culture medium. This implies that these three components are indispensable in shaping the culture medium by virtue of increased cell growth. The maximum cell viability according to the model is $1.7 \times 10^{9} \mathrm{CFU} / \mathrm{mL}$.
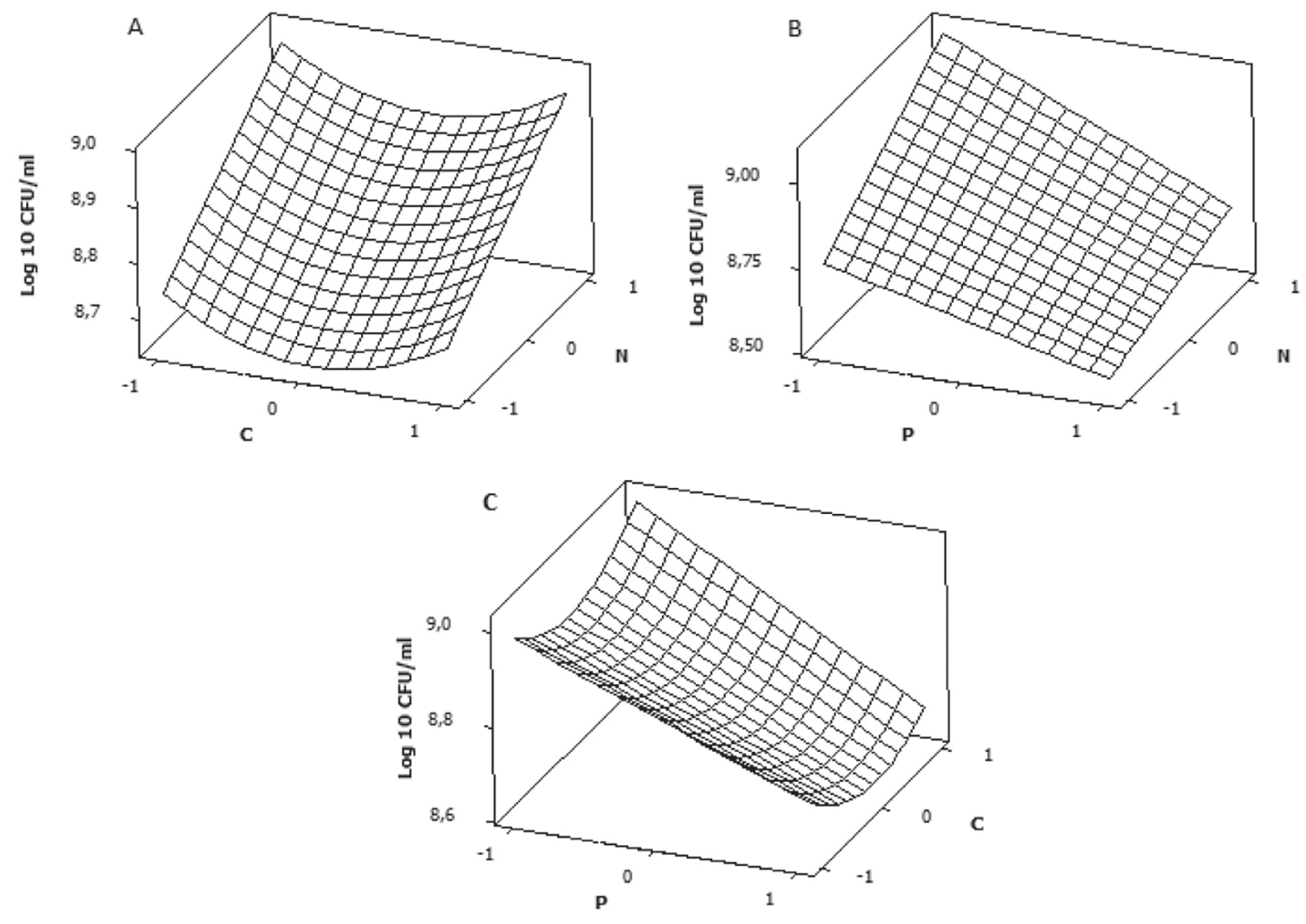

Figure 3. Cube plot for three factors with cell growth $(\mathrm{CFU} / \mathrm{mL})$ as a response variable. Carbon $(\mathrm{C})$, nitrogen $(\mathrm{N})$ and phosphorus $(\mathrm{P})$.

The presence of carbon, nitrogen and phosphorus is essential for a microorganism to perform its main metabolic functions which allow it to survive. However, before a microorganism can use these nutrients, they must first be able to detect the type and amount of nutritional sources available in order to adjust their metabolism in their environmental conditions. Many of these 
metabolic responses are due to the interaction of carbon and nitrogen metabolism products, for example phosphotransferase systems (PII), and other DNA binding factors [25]. This initial phase, known as lag phase, is an adaptation period in which the bacteria synthesizes a large amount of cell components such as RNA for the production of proteins, enzymes, polysaccharides, fatty acids among and others, in order to activate metabolic pathways with the goal of preparing the cell machinery to enter the exponential phase [26] [27].

As well as carbon and nitrogen, phosphorus also has a leading role in the activation of cell metabolism that allows adaptation to environmental fluctuations. In bacteria, the response to these environmental shifts are given by signal transduction mechanisms, where the anchoring of peptides with transmembrane proteins function under two-component systems, where the activation is mediated by phosphorylation and methylation to trigger the adaptation responses [28]. In Bacillus subtilis, there are three adaptation systems, mediated by two-component systems, which are involved in the nutrient's detection and cell motility toward them, [29]. For example, under limiting phosphate concentrations, the PhoR-PhoB two-component system starts operating [32]. The aspartic residue of the kinase sensor is phosphorylated, which subsequently will activate the response regulator and will bind to DNA sequences known as "PHO boxes", in order to regulate the repression or activation of the $\mathrm{PHO}$ regulon [33].

Likewise, phosphorus is necessary for other bacteria genetic regulation responses in the activation of adaptation systems due to nutritional stress conditions. For instance, the activation of the sigma factor $\mathrm{B}(\sigma \mathrm{B})$, one of the RNA polymerase subunits, contributes to the expression of more than 200 genes involved in the metabolic responses to this stress [30].

Phosphorus has a global regulation mechanism responsible for handling inorganic phosphorus in the bacterial cell. This mechanism is composed of extracellular enzymes responsible for obtaining inorganic phosphorus and transform it into organic phosphorus, which is favored by the presence of carbon and nitrogen in the environment [31].

The influence of carbon sources in the phosphorus regulation systems has been reported [32]. For this study, it was observed that the high concentration of phosphorus and glucose have a negative effect on cell growth. The effect was described by [34], who observed that it was the low concentration of phosphorus that had a positive effect on cell growth.

Based on regression coefficients and significance of factors calculated by the complete factorial design, the equation describing the linear model obtained with a value of $R^{2} 99.96 \%$ is presented below:

$$
\begin{gathered}
Y=792500000+22500000 C+237500000 N-275000000 P+42500000 C^{\star} N-70000000 \\
C^{\star} P-145000000 N^{\star} P-115000000 C^{\star} N^{\star} P-205833333 \text { Central Point }
\end{gathered}
$$

Where $\mathrm{Y}$ represents the response variable $(\mathrm{CFU} / \mathrm{mL}) ; \mathrm{C}$ represents the concentration of carbon source; $\mathrm{N}$ represents the concentration of nitrogen source and $\mathrm{P}$ represents the concentration of phosphorus source.

Based on the obtained model, the optimal concentrations of the culture media components to reach the highest viable biomass production of Bacillus subtilis 168 are the following: $10 \% \mathrm{~m} / \mathrm{v}$ of carbon source (liquid molasses), $1 \% \mathrm{~m} / \mathrm{v}$ of nitrogen source (ammonium nitrate), and 0,01\% $\mathrm{m} / \mathrm{v}$ of phosphorus source $\left(\mathrm{K}_{2} \mathrm{HPO}_{4}\right)$. 


\section{Conclusions}

Costa Rica generates AR that can be valued as a low-cost growth culture medium and which can eventually be transformed into high value products through biotechnological processes. Liquid molasses and wheat bran, as sources of carbon and nitrogen, respectively, show satisfactory results to produce viable bacterial biomass. For the elaboration of a liquid culture medium, the optimal concentrations to be used in the culture medium are $10 \% \mathrm{~m} / \mathrm{v}$ for molasses as carbon source, $5 \% \mathrm{~m} / \mathrm{v}$ for wheat bran as nitrogen source and $0.01 \% \mathrm{~K}_{2} \mathrm{HPO}_{4}$ as source of phosphorus. For future experiments it is recommended to carry out chemical characterization of the substrates to be used in order to perform a better control and standardization of the bioprocess.

\section{References}

[1] S. Saval, "Aprovechamiento de residuos agroindustriales: Pasado, presente y futuro," Bio-Tecnología, vol. 16, no. 2, pp. 14-46, 2012.

[2] L. H. Amaya, C. T. Serna, y C. V. Tovar, "Aprovechamiento de subproductos agropecuarios," Universidad Nacional Abierta y a Distancia, Sogamoso, Colombia, Contenido Didáctico del Curso, 2011 [en línea]. Disponible en: http://stadium.unad.edu.co/preview/UNAD.php?url=/bitstream/10596/8911/1/Aprovechamie nto\%20de\%20Subproductos\%20Agropecuarios.pdf

[3] X. Wu, J. McLaren, R. Madl, y D. Wang, "Biofuels from lignocellulosic biomass," en Sustainable Biotechnology, O. Singh, y S. Harvey, eds, Dordrecht, Holanda, pp. 19-41, 2010.

[4] P.T. Vasudevan, M. D. Gagnon, y M. S. Briggs, "Environmentally sustainable biofuels-The case for biodiesel, biobutanol and cellulosic ethanol," en Sustainable Biotechnology, O. Singh, y S. Harvey, eds, Dordrecht, Holanda, pp. 43-62, 2010.

[5] A. K. Chandel, O. V. Singh, y L. V. Rao, "Biotechnological applications of hemicellulosic derived sugars: stateof-the-art," en Sustainable Biotechnology, O. Singh, y S. Harvey, eds, Dordrecht, Holanda, pp. 63-81, 2010.

[6] V. Ferreira-Leitão, L. M. Gottschalk, M. A. Ferrara, A. L. Nepomuceno, H. B. Molinari, y E. P. Bon, "Biomass residues in Brazil: availability and potential uses," Waste and Biomass Valorization, vo. 1, no. 1, pp. 65-76, 2010.

[7] A. L. Demain, "The business of biotechnology," Industrial Biotechnol, vol. 3, no. 1, pp. 269-283, 2007.

[8] E. J. Vandamme, "Microbial gems: Microorganisms without frontiers," SIM-News, vol. 57, no. 3, pp. 81-91, 2007.

[9] P. Gallezot, "Conversion of biomass to selected chemical products," Chemical Society Reviews, vol. 41, no. 4, pp. 1538-1558, 2012.

[10] D. R. Zeigler, Z. Prágai, S. Rodriguez, B. Chevreux, A. Muffler, T. Albert, ... y J. B. Perkins, "The origins of 168, W23, and other Bacillus subtilis legacy strains," Journal of Bacteriology, vol. 190, no. 21, pp. 6983-6995, 2008.

[11] K. Stephenson, y C. R. Harwood, "Influence of a cell-wallassociated protease on production of alpha-amylase by Bacillus subtilis," Appl. Environ. Microbiol., vol. 64, pp. 2875-2881, 1998.

[12] V. Barbe, S. Cruveiller, F. Kunst, P. Lenoble, G. Meurice, A. Sekowska, y A. Danchin, "From a consortium sequence to a unified sequence: the Bacillus subtilis 168 reference genome a decade later," Microbiology, vo. 155, no. 6, pp. 1758-1775, 2009.

[13] G. A. Płaza, P. Pacwa, Z. Piotrowska, K. Jangid, y K. A. Wilk, "Agroindustrial wastes as unconventional substrates for growing of Bacillus strains and production of biosurfactant," Environ Prot Eng, vol. 37, no. 1, pp. 63-71, 2011.

[14] D. Ghribi, y S. Ellouze-Chaabouni. "Enhancement of Bacillus subtilis lipopeptide biosurfactants production through optimization of medium composition and adequate control of aeration". Biotechnology Research International. Vol. 2011. pp- 1-6, 2011.

[15] F.F. Cavalcante, A.P. Resende, C.J. de Andrade, G.M. Pastore. "Production of Enzymes from Agroindustrial Wastes by Biosurfactant-Producing Strains of Bacillus subtilis". Biotechnology Research International. vol. 2013, pp. 1-9, 2013.

[16] M.A. Younis, F.F. Hezayen, M.A. Nour-Eldein, y M.S. Shabeb. "Optimization of cultivation medium and growth conditions for Bacillus subtilis KO strain isolated from sugar cane molasses". Am Eurasian J Agric Environ Sci. vol. 7, no. 1, pp. 31-37, 2010. 
[17] Minitab Inc, Versión 16, Estados Unidos, 2015.

[18] P. S. Murthy, y M. M. Naidu, "Sustainable management of coffee industry by-products and value addition—A review," Resoures, Conservation and Recycling, vol. 66, pp. 45-58, 2012.

[19] P. Esquivel, y V. M. Jiménez, "Functional properties of coffee and coffee by-products," Food Research International, vol. 46, no. 2, pp. 488-495, 2012.

[20] J. Aguilar, M. Espinoza, J. Cabanillas, I. Ávila, A. García, J. Julca, y G. Linares, "Evaluación de la cinética de crecimiento de Saccharomyces cerevisiae utilizando un medio de cultivo a base de melaza de caña y suero lácteo," Agroindustrial Science, vol. 5, no. 1, pp. 37-47, 2015.

[21] I. M. Banat, S. K. Satpute, S. S. Cameotra, R. Patil, y N. V. Nyayanit, "Cost effective technologies and renewable substrates for biosurfactants' production," Frontiers in microbiology, vol. 697, no. 5, pp. 1-18, 2014.

[22] J. D. J. S. Legazpi, y J. A. O. Fierro, "Análisis de la producción azucarera en el occidente de México: Caso: valle El Grullo-Autlán, Costa Sur de Jalisco," CIBA Revista Iberoamericana de las Ciencias Biológicas y Agropecuarias, vol. 2, no. 3, pp. 1-23, 2014.

[23] O. Tabbene, I. B. Slimene, K. Djebali, M. L. Mangoni, M. C. Urdaci, y F. Limam, "Optimization of medium composition for the production of antimicrobial activity by Bacillus subtilis B38," Biotechnology progress, vol. 25, no. 5, pp. 1267-1274, 2009.

[24] C. López, R. Hernández, C. Suárez, y M. Borrero, "Evaluación del crecimiento y producción de Pleurotus ostreatus sobre diferentes residuos agroindustriales del departamento de Cundinamarca," Universitas Scientiarum, vol. 13, no. 2, pp. 128-137, 2008.

[25] F. M. Commichau, K. Forchhammer, y J. Stülke, "Regulatory links between carbon and nitrogen metabolism," Current Opinion in Microbiology, vol. 9, no. 2, pp. 167-172, 2006.

[26] E. C. Álvarez, y L. C. Sánchez, "Evaluación del crecimiento de cuatro especies del género Bacillus sp., primer paso para entender su efecto biocontrolador sobre Fusarium sp.," Nova, vol. 14, no. 26, pp. 53-62, 2016.

[27] I. A. M. Swinnen, K. Bernaerts, E. J. Dens, A. H. Geeraerd, y J. F. Van Impe, "Predictive modelling of the microbial lag phase: a review," International Journal of Food microbiology, vol. 94, no. 2, pp. 137-159, 2004.

[28] M. A. Zimmer, J. Tiu, M. A. Collins, y G. Ordal, "Selective Methylation Changes on the Bacillus subtilis Chemotaxis Receptor McpB Promote Adaptation," The Journal of Biological Chemistry, vol. 275, no. 32, pp. 24264-24272, 2000.

[29] C. V. Rao, G. D. Glekas, y G. W. Ordal, "The three adaptation systems of Bacillus subtilis chemotaxis," Trends in Microbiology, vol. 16, no. 10, pp. 480-487, 2008.

[30] F. J. de Bruijn, "Stress and environmental regulation of gene expression and adaptation in bacteria: volume 2" New Jersey, Estados Unidos: John Wiley \& Sons, Inc., 2016.

[31] N. U. Maheswar, y G. Sathiyavani, "Solubilization of phosphate by Bacillus sp, from groundnut rhizosphere (Arachishypogaea L)," Journal of Chemical and Pharmaceutical Research, vol. 4, no. 8, pp. 4007-4011, 2012.

[32] A. Puri-Taneja, S. Paul, Y. Chen, y F. M. Hulett, "CcpA causes repression of the phoPR promoter through a novel transcription start site, PA6," Journal of Bacteriology, vol 188, no. 4, pp. 1266-1278, 2006.

[33] D. White, "The physiology and biochemistry of prokaryotes," Oxford University Press, Reino Unido, pp. 628, 2007.

[34] J. A. Grahovac, Z. Z. Roncević, I. Ž. Tadijan, A. I. Jokić, y J. M. Dodić, "Optimization of media for antimicrobial compounds production by Bacillus subtilis,". Budapest Acta Alimentaria, vol. 44, no. 3, pp. 427-435, 2015. 